\title{
Changing Pathology with Changing Drugs: Tumors of the Gastrointestinal Tract
}

\author{
Pascale Cervera Jean-François Fléjou \\ Service d'Anatomie et Cytologie Pathologiques, Hôpital Saint-Antoine, AP-HP, Faculté de Médecine \\ Pierre-et-Marie-Curie, et INSERM UMRS 938, Paris, France
}

\begin{abstract}
Key Words
Gastrointestinal cancer $\cdot$ Colon cancer $\cdot$ Molecular

pathology $\cdot$ Targeted therapy
\end{abstract}

\begin{abstract}
Gastrointestinal cancer treatment is being based more and more on pathology that yields integrated information leading to targeted therapy, i.e. morphological identification of the histological type of the tumor and its context, staging of the tumor, and identification of various targets. This provides a realistic appraisal of the tumor and allows surgeons and oncologists to choose the best treatment from an increased range of drug options. An accurate diagnosis remains the major determinant of treatment, but new drugs and new insights into molecular pathways acting in carcinogenesis enhance molecular diagnosis in cancer. In most adenocarcinomas, therapy is only organ orientated and staging dependent, and not patient targeted. Currently, the identification and validation of new targets as well as molecular classification of the tumors are inducing the incorporation of new tests into the daily practice of surgical pathology. These new tests require appropriate tissue preservation and selection of the tissue to be analyzed and harmonized to morphological criteria. In colorectal adenocarcinoma, which is the second most common malignant tumor in both genders, the biomarkers that are relevant at the present time are the genetic instability status of the tumor, the KRAS mu-
\end{abstract}

tation status as a negative predictive marker for the overall rate of response to anti-EGFR treatment in patients with metastatic cancer, and BRAF mutation as an unfavorable prognostic marker. In gastric adenocarcinoma, HER2 overexpression is correlated with poor outcomes and more aggressive disease in a subset of cases with clinical response to trastuzumab. Met mutations have also been evidenced. Hepatocellular carcinoma is a highly chemoresistant tumor with several genetic alterations. Pancreatic adenocarcinoma is a leading cause of cancer death with frequent KRAS mutations. No biomarker has been clearly identified in either of these tumors. Gastrointestinal stromal tumors that constitute less than $3 \%$ of all gastrointestinal malignancies have been individualized since 1988. They express the KIT protein, a membrane receptor, and respond to imatinib which is a tyrosine kinase receptor inhibitor, depending on the mutational status of the tumor. Copyright $\odot 2011$ S. Karger AG, Basel

In cancer medicine, new drugs have considerably changed the pathology and treatment of several malignant diseases. The purpose of this article is to illustrate how the diagnosis, biology, and treatment of certain neoplastic disorders of the digestive tract have already changed or will change with the arrival of drugs that are in the introductory phase of their development and how these changes will impact the practice of pathology. Can-

\section{KARGER \\ Fax +4161306 1234 \\ E-Mail karger@karger.ch}

www.karger.com
(C) 2011 S. Karger AG, Basel

$1015-2008 / 11 / 0782-0076 \$ 38.00 / 0$

Accessible online at:

www.karger.com/pat
Dr. Pascale Cervera

Service d'Anatomie et Cytologie Pathologiques

Hôpital Saint-Antoine, 184, rue du Faubourg Saint-Antoine

FR-75012 Paris (France)

Tel. +33 149282 172, E-Mail pascale.cervera@sat.aphp.fr 
cer was first considered as a single disease and the vision of cancer focused on the common proliferative aspect of the disease. Traditional cancer cytotoxic drugs act directly on cell proliferation, interfering with mitosis (alkaloids), DNA synthesis (alkylating agents and antimetabolites), microtubules (taxanes), and repair systems (nitroureas) in a nonspecific way, with general clinical consequences and failure to durably repress recurrence in patients [1], as evidenced by the mortality rates over the past 3 decades [2]. Cancer, however, despite sharing common aberrant alterations, is not a single process but is rather a heterogeneous constellation of tumoral processes [3] with different clinical histories, morphological aspects, grading, and pathological stages as well as various sensibilities to classical cytotoxic drugs.

Our understanding of carcinogenesis has evolved as the interconnecting network of cellular signaling pathways involving extracellular ligands, transmembrane receptors, intracellular signaling protein kinases, and transcription factors has been further elucidated [4]. These intracellular signaling effectors are modulated by external factors such as epigenetic changes, oncogenetic mutations, molecular chaperones, and ubiquitin-proteasome pathways and, when superactivated, cancer initiators [5]. Insights into these complex intracellular processes have rendered a new vision of pathology with the appearance of new pathological entities. Many novel cancer targets stimulating the uncontrolled multiplication of the tumor cells are now exposed for chemotherapeutic agents not only acting on general mitotic mechanisms but also improving the survival and quality of life of some patients [6-9]. These novels cancer targets generate biomarkers.

The pathologist acts in the individualization of these molecular relevant entities, in the screening of pertinent predictive markers, and in the recommendation of selected markers of clinical utility in routine use that are directly linked to therapeutics.

The pathologist has the following tools at his own disposal for this new semiology:

- Morphological assessment of the tumor that cannot be accomplished by 'grind-and-blind' methodologies failing to preserve topography [10] but is evaluated simply on H\&E-stained slides at the microscopic level. This morphological assessment remains largely an interpretative skill which cannot be automated. Accurate diagnosis is the major determinant of treatment. Diagnosis of the histological type of the tumor and evaluation of the prognostic indicators including surgical margin status, lymph node metastases, and perineural and angiolymphatic invasion are still the core of pathology practice and the first step for treatment selection and targeted therapy. In adenocarcinoma, therapy is organ orientated and not patient targeted $[11,12]$.

- Identification of tumor heterogeneity with the tumoral microenvironment including new blood vessels resulting from angiogenesis, stromal cells, and inflammatory cells.

- Molecular pathology that can be used to assist in classifying tumors for prognostic purposes and to analyze the potential to respond to therapeutic agents. The pathologist, who has a realistic appraisal of the disease, can make an optimal test selection and an integration of molecular or genetic testing to clinical data. The technologies used to identify biomarkers rely on the amplification of nucleic acids (polymerase chain reaction), DNA, RNA and protein sequence analysis, epigenetics, transcriptome microarrays, in situ hybridization, and immunohistochemistry (IHC) that can be performed on formalin-fixed paraffin-embedded tissue or a frozen specimen. Bouin fixative must be banished. This assessment can be made on biopsies or surgical specimens from the primitive tumor or on metastases (fig. 1). The amount of DNA has to be sufficient and the percentage of tumoral tissue against normal tissue has to be as high as possible (at least 30\%), taking into account the cellularity of the stroma, requiring pathology expertise. The methods for mutation testing rely on PCR. A thorough analytical validation of testing methods, together with a high standard of quality assurance, is critical for accurate, reliable mutation testing in clinical practice. The most common and relatively inexpensive method is sequencing after PCR, but it is not the most sensitive [13]. Analysis of protein expression by IHC is essential in the assessment of pathology specimens and their various gene products. Interphase fluorescent or chromogenic in situ hybridization refers to the visualization of chromosomal aberrations in intact nuclei using probes indirectly revealed or directly labeled. The identification of both numerical and structural chromosome anomalies in the interphase nucleus allows the assessment of chromosomal aberrations, cellular phenotype, and tissue morphology with a highly sensitive technique when it concerns a small percentage of tumor cells in a specimen. In situ hybridization can detect centromeres to enumerate the changes in the chromosome copy number, deletions/allelic losses, duplications/allelic gains, amplifications of specific chromosome regions or genes, and chromosome translocations [14]. 

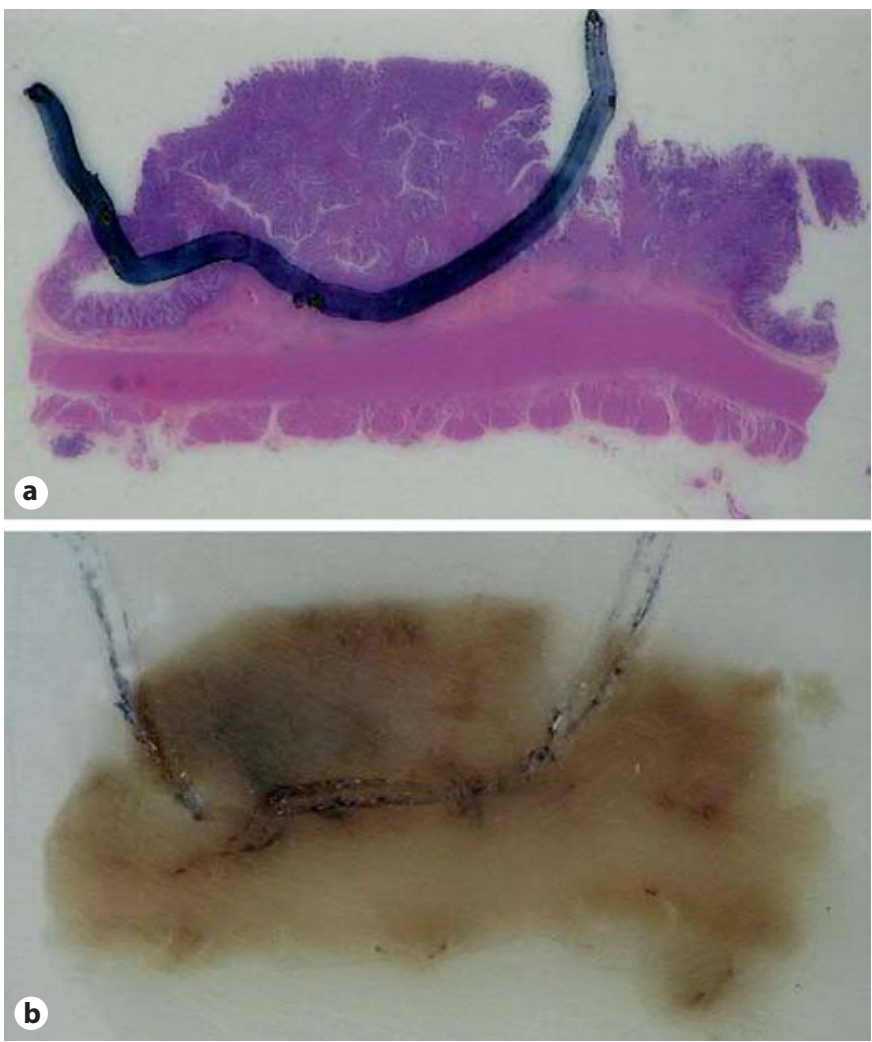

Fig. 1. Tumor sampling for molecular studies. a Hemalun-phloxin section of colorectal carcinoma after selection of the appropriate tumor specimen. b Macrodissection on the paraffin corresponding block to obtain the highest percentage of tumoral tissue against normal tissue.

The biomarkers are chosen in the pathways controlling cell growth, proliferation, and differentiation, such as the RAS-RAF-MAP kinase pathway and the PI3KPTEN-Akt pathway, the activation of which leads to malignant transformation, angiogenesis, and metastatic dissemination [15]. The specifically targeted aberrancies in tumor and stromal cells can be conceptualized as membrane-bound receptor kinases such as hepatocyte growth factor (HGF)/c-Met [16], human epidermal factor receptor $[17,18]$ and insulin growth factor receptor pathways [19], intracellular signaling kinases like Src, PI3k/Akt/mTOR [20] and mitogen-activated protein kinase (MAPK) pathways [21], epigenetic abnormalities (DNA methyltransferase and histone deacetylase), protein dynamics (heat shock protein 90, ubiquitin-proteasome system), and tumor vasculature and microenvironment by way of vascular endothelial growth factor and receptors [22], hypoxia-inducible factors [23], and direct targeting of endothelial cells by vascular disrupting agents like tubulin destabilizers and flavonoids (fig. 2) [24, 25].

Several technologies such as cancer vaccines, antisense oligonucleotides, and small interfering RNAs are available to target these abnormalities [26-31]. Of these, monoclonal antibodies (MoAbs) and small-molecule inhibitors have been the most successful [25].

Targeted therapy is based on MoAbs and small-molecule protein kinase inhibitors. Therapeutic use of these MoAbs in cancer patients became possible after the development of hybridoma technology by Kohler and Milstein [32] in 1975. Early murine MoAbs performed poorly in the clinical setting partly because of a short antibody half-life and the immunogenicity of murine antigens in human hosts. The production of chimeric and humanized MoAbs overcame these disadvantages, leading to better clinical development. The MoAb approach is particularly suited for membrane-bound targets. Proposed mechanisms of action include interference with ligandreceptor interaction, antibody-dependent cellular toxicity, complement-mediated cytotoxicity, and immune modulation [31]. Small-molecule protein kinase inhibitors are efficacious against both membrane-bound and non-membrane-bound targets. They are ATP analogs, catalytic domain binders, natural products, and inactive kinase conformation binding ligands (fig. 2) [25].

In this article, emphasis is made on the task of the pathologist in the management of digestive cancers through identification of the current relevant genetic alterations that allow individualized and targeted chemotherapy based not only on histological typing and grading but also on molecular alterations, increasing the complexity of tailoring cancer drugs.

\section{Colorectal Adenocarcinoma}

Colorectal cancer (CRC) is the second most frequent malignant tumor in both genders. With more than 36,000 new cases and 15,000 deaths a year in France, the 5-year survival rate for CRC is about $50-60 \%$. Up to $20 \%$ of new cases present with metastatic disease. In stage II, $34 \%$ of patients present recurrences.

While for many years the diagnosis and therapy of CRC did not change drastically, new drugs have revolutionized the field. Despite an almost identical histopathological type, two different molecular mechanisms of colorectal carcinogenesis have been identified: 


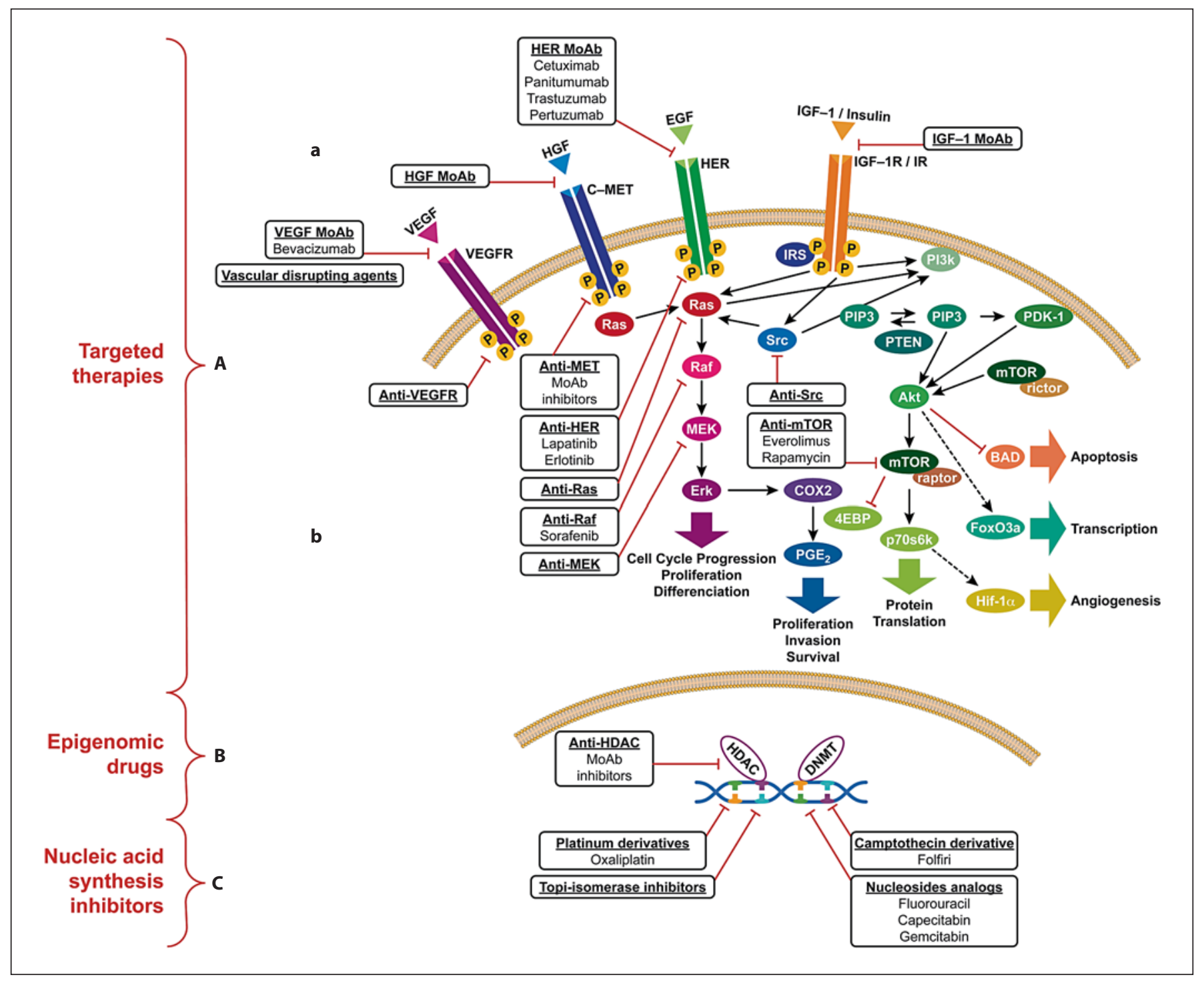

Fig. 2. Cancer drugs and their mechanisms of action. A Cellular signaling pathways involved in proliferation, angiogenesis, and differentiation, with their therapeutic targets. a Membranebound human epidermal growth factor receptors (HER), c-MET, and insulin-like growth factor 1 receptor (IGF-1R) mediate mitogenic signals from extra-cellular ligands, such as epidermal growth factor (EGF), hepatocyte growth factor (HGF), and insu-

- Chromosomal instability which, characterized by recurrent allelic losses that contribute to the inactivation of tumor suppressor genes, is not actually by itself a chemotherapeutic target.

- Genetic instability due to the inactivation of the mismatch repair (MMR) system, the system that regulates DNA fidelity and base excision repair leading to microsatellite instability (MSI).

Tumors of the Gastrointestinal Tract lin growth factors (IGF), respectively. b The Ras/Raf/MEK/Erk (mitogen-activated protein kinase, MAPK) and PI3k/Akt/mTOR pathways regulate intracellular signaling traffic. B Epigenetic DNA methyl transferases (DNMT) and histone deacetylases (HDAC) modulate the expression of oncogenes and tumor suppressor genes. C Drugs acting on DNA synthesis. The drug agents and their targets are indicated in boxes.

\section{Genetic Instability}

This is the cause of hereditary non-polyposis CRC; it accounts for $1-2 \%$ of CRCs. However, $15 \%$ of sporadic CRCs have an inactivated MMR system owing to the aberrant methylation of hMLH1. This aberrant methylation can mediate transcriptional silencing by recruiting methyl-binding proteins that recognize methylated sequences and recruit histone deacetylase. Histone deacetylase in- 

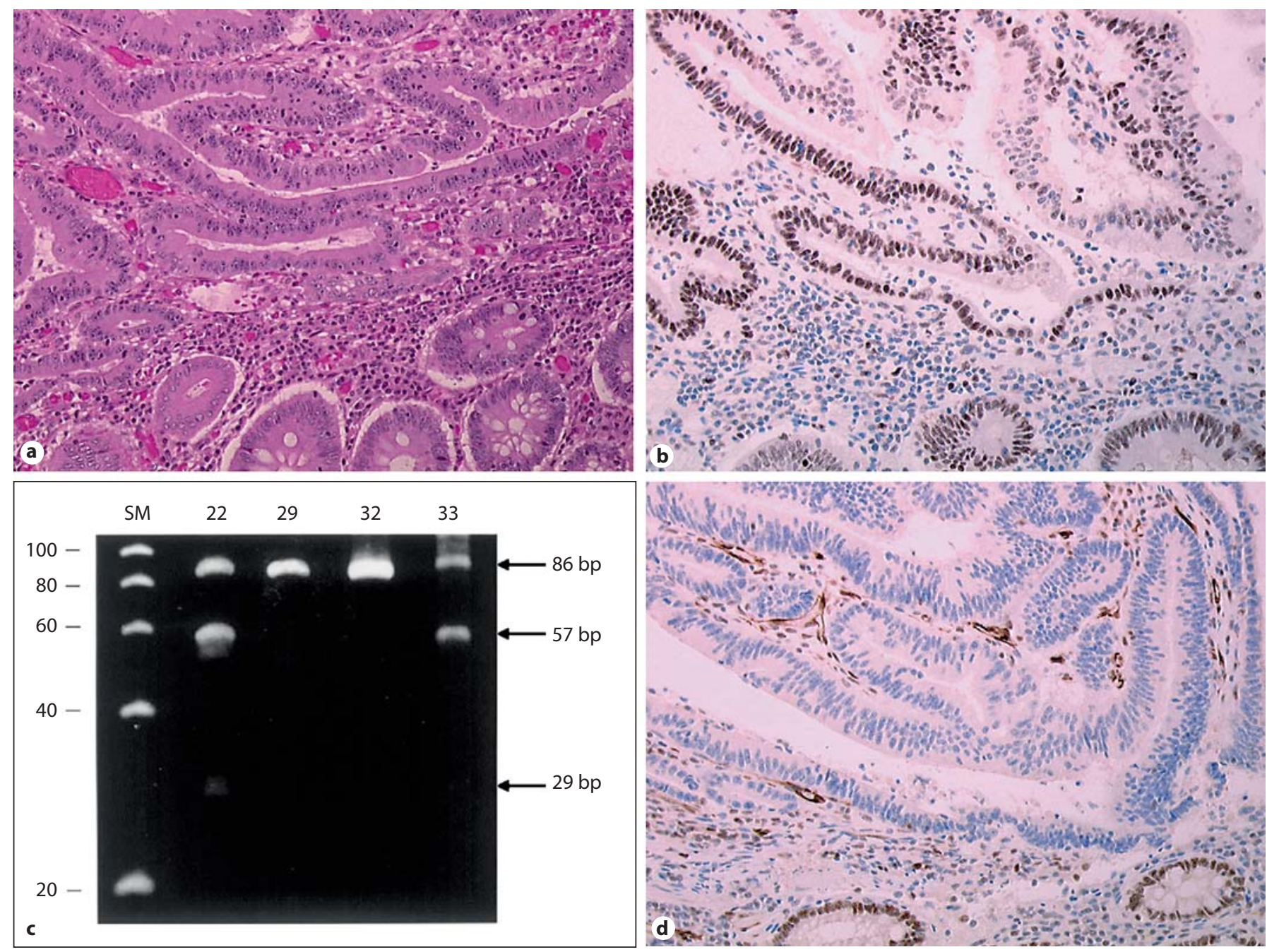

Fig. 3. Microsatellite instability in colorectal adenocarcinoma. a H\&E section shows a well-differentiated adenocarcinoma with a glandular pattern beside normal mucosa. b hMSH2 IHC evidences no loss of expression. c hMLH1 IHC evidences loss of nuclear expression of the corresponding protein. $\mathbf{d}$ Hypermethylated alleles are cleaved; cases 22 and 33 induced silencing of hMLH1.

duces changes in chromatin structure, impeding the access of transcription factors to the promoter [33]. It is possible to target these histone changes and methylation with histone deacetylase inhibitors [34]. Other epigenetic alterations, like the methylation of oncostatin $\mathrm{M}$ receptor-beta (OSMR), are found in primary colon cancer tissue. Promoter methylation-mediated silencing of OSMR in cell lines and CRC cells with low OSMR expression are resistant to growth inhibition by oncostatin M. These data highlight a new therapeutic target in colorectal carcinoma. Moreover, the detection and quantification of OSMR promoter methylation in fecal DNA is a highly specific diagnostic biomarker for CRC [35].
Genetic instability can predict tumor recurrence in patients with stage III CRC, as does $18 \mathrm{q}$ deletion. Prognostic analyses have shown an increased relapse-free survival for MSI CRCs compared with microsatellite-stable tumors. MSI is very unusual in CRC with liver metastasis [36]. Loss of hMLH1/hMSH2 expression (fig. 3) is a prognostic and predictive highly sensitive and specific biomarker indicating a low frequency of distant metastases. Therefore, MSI is a good prognostic factor but it is not a clear predictive marker of the benefit of chemotherapy unless it is used in non-targeted therapy [37-39]. MSI (fig. 4) predicts a failure of response to adjuvant 5-FU monotherapy and there is no evidence of a value of MSI 


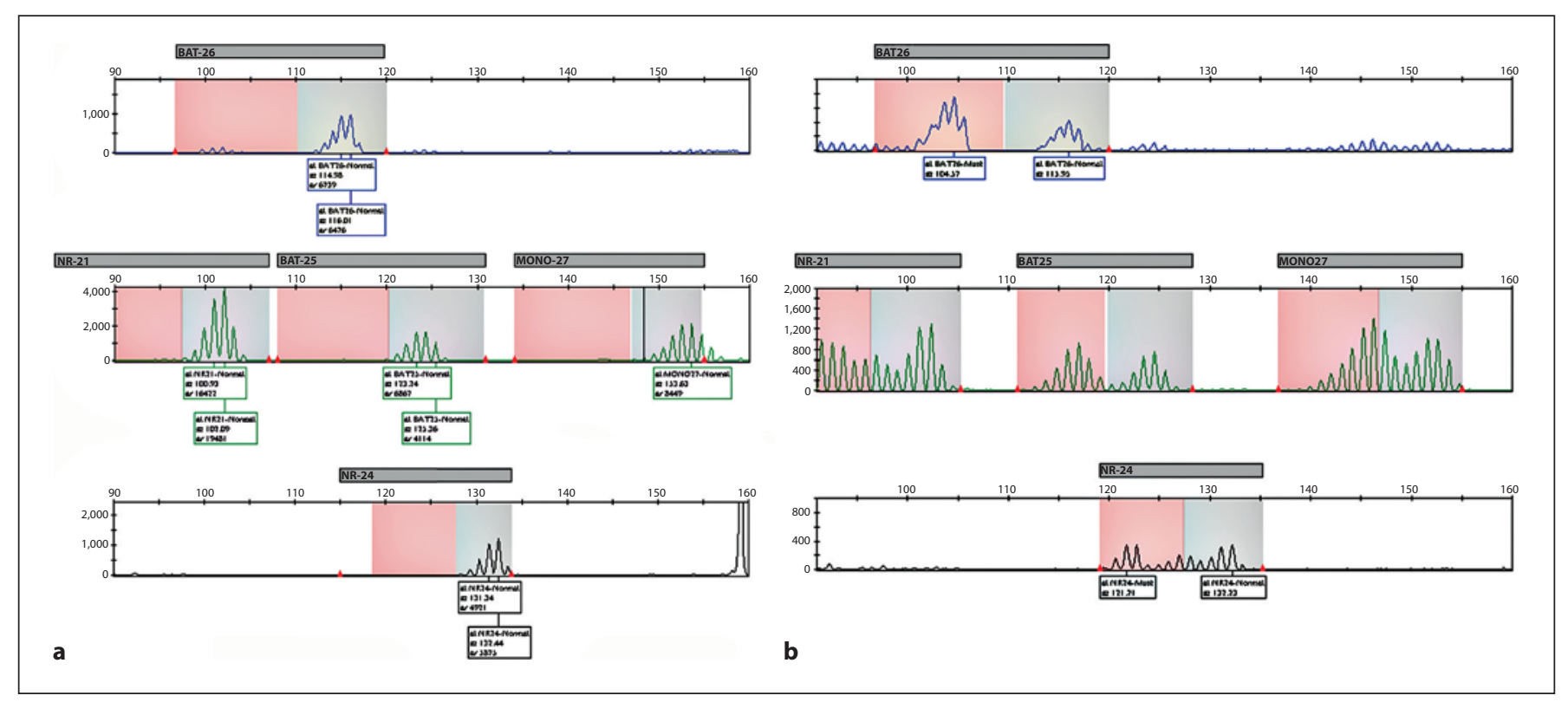

Fig. 4. Microsatellite instability. To confirm MSI, a panel of 5 markers was used, i.e. BAT25, BAT26, NR21, NR22, and NR24, amplified by multiplex PCR. a MSI- tissue control. b MSI+ tumor showing shortening of the 5 markers.

for a Folfox treatment combination in metastatic CRC. MSI predicts the response to adjuvant irinotecan/5FU/ leucovorin when Folfox cannot be used [40, 41]. MSI status and p53 expression may influence the impact of oxaliplatin in the adjuvant treatment of stage III colon cancer patients [42].

\section{The RAS-RAF-MAP Kinase Pathway}

Among the growth factors interacting with the MAP kinase signal transduction pathway via receptors, EGFR is a natural molecular target for a new class of anticancer drugs [15]. When EGFR is overexpressed, 2 MoAbs that recognize the extracellular domain of the receptor leading to its inactivation have been incorporated into clinical practice for the treatment of metastatic disease: i.e. cetuximab and panitumumab [43-45]. Both drugs improved the survival rate of $10 \%$ of patients with metastatic CRC, pointing to the need for simple tests able to predict a response to these agents. EGFR protein expression detected by IHC in cancer specimens is insufficient to determine the response to cetuximab therapy [46] and it is no longer used. The EGFR gene copy number gain (due to either polysomy or gene amplification), evaluated by fluorescent in situ hybridization (FISH), seems to be a better predictive marker for anti-EGFR MoAb sensitivity, whereas the presence of KRAS mutations and/or loss of
PTEN protein expressed by IHC predicts the resistance to these drugs [47-53].

Indeed, one of the most important proto-oncogenes in colon carcinogenesis is a member of the RAS family of genes, i.e. KRAS2; it is involved in signal transduction, coupling growth factors to the RAF-MAPK signal transduction pathway which leads to the expression of early response genes to propagate cell proliferation. KRAS2 mutations can be detected in $37-41 \%$ of CRCs (fig. 5). There is agreement between the primary tumor and related metastasis for the deregulation of EGFR downstream members. The observation that posttranslational modifications, such as farnesylation, are required for membrane localization and the activation of Ras has led to an interest in developing farnesyltransferase inhibitors such as Ras inhibitors [54]. BRAF, which is a serine-threonine kinase of the RAS-RAF pathway activated by RAS may represent a novel predictive marker for the anti-EGFR drug response [52]. KRAS and BRAF mutations are mutually exclusive [55]. The BRAF G12D mutation confers a more aggressive phenotype. The G12V mutation correlates with an indolent course [52].

Sorafenib (Bay43-2006) is an oral, dual inhibitor of Raf. Intracellular signaling kinases (Src) are non-receptor tyrosine kinases, the first proto-oncogenes to be 


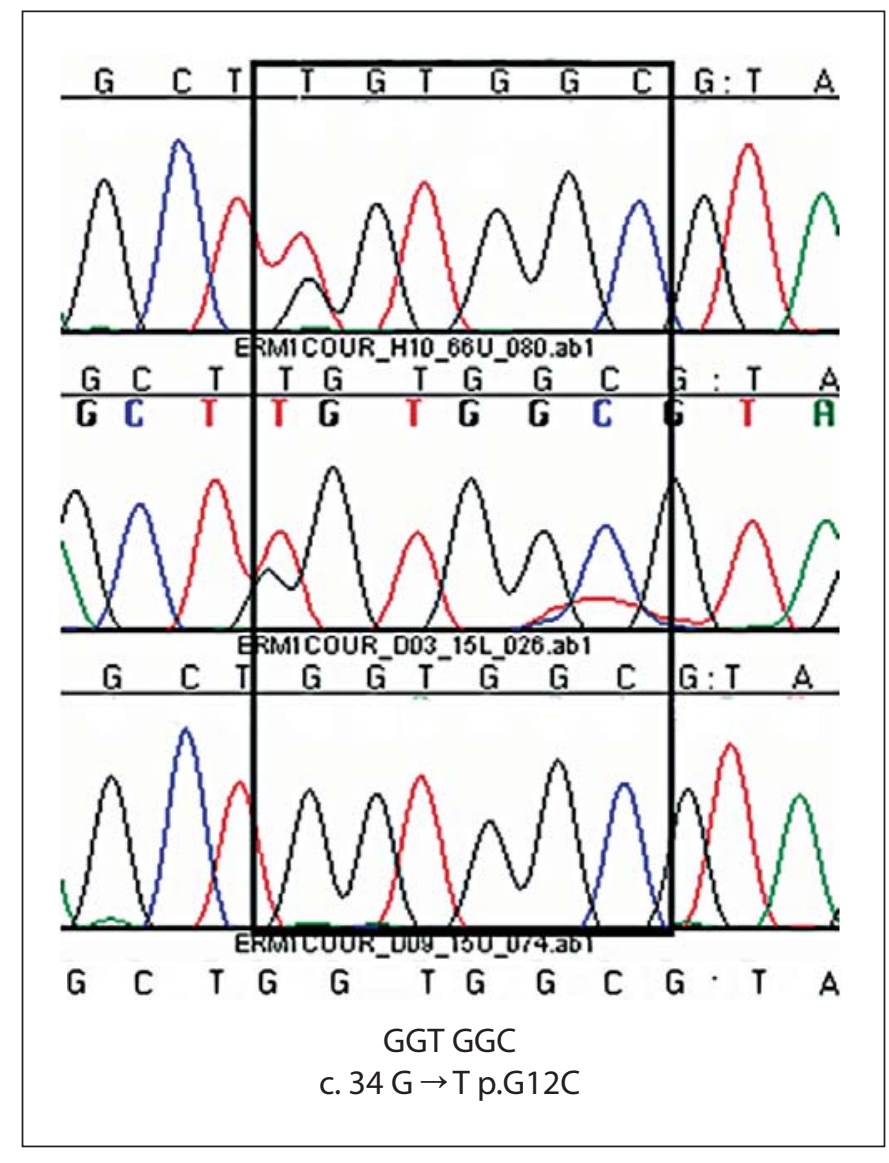

Fig. 5. KRAS mutation in colorectal adenocarcinoma, evidenced by sequence analysis, focusing on codons 12 and 13. DNA change, $34 \mathrm{G} \rightarrow \mathrm{T}$; amino acid change, G12C.

described. They mediate the mitogenic signal between growth factor receptors, such as EGFR, c-MET, and IGF$1 \mathrm{R}$, and downstream signaling cascades like focal-adhesion kinase. Activation of the PI3k/Akt/mTOR pathway resulting from aberrant events including loss of PTEN function is associated with a poor prognosis and contributes to chemoresistance in many types of cancers [56].

The aims of molecular clinical studies are to analyze molecular alterations predictive of the anti-EGFR therapy response, such as EGFR gene status, KRAS, and BRAF mutations (according to FDA and EMEA guidelines), and PTEN protein expression in primary and synchronous or metachronous metastases. BRAF status is weakly associated with lack of response, but it is strongly associated with shorter progression-free survival. EGFR amplification and cytoplasmic expression of PTEN seem to be associated in KRAS wild-type metastatic CRC with response in cetuximab-based treatment [57].
The relationship between inactivation of the MMR pathway and other genetic alterations frequently found in $\mathrm{CRC}$ is partially understood. The incidence of KRAS mutations appears to be high (22-33\%), with a similar rate to that observed in microsatellite-stable cancers $[58,59]$. BRAF mutations are most frequent in these tumors [60].

However, even the evaluation of these additional molecular markers is not able to fully predict the EGFR-targeted drug response, leading to consideration of the involvement of other genes or markers like nuclear EGFR that could contribute to acquired resistance to cetuximab or the favorable impact on the cetuximab response of a combination of the genotype FcyRIIIa-131HH and/or FcyRIIIa-158VV of the receptors activating antibody-dependant cellular cytotoxicity $[61,62]$.

\section{Angiogenesis Inhibitors}

Tumors are unable to grow beyond $2 \mathrm{~mm}^{3}$ unless they are supported by neovascularization [63]. Vascular endothelial growth factor receptor-2 (VEGFR-2) mediates angiogenic signals from ligands such as vascular endothelial growth factor (VEGF), fibroblast growth factor, and HGF in the formation of new tumor vasculature [64]. Numerous anti-VEGF/VEGFR MoAbs and small-molecule inhibitors, such as bevacizumab, are currently used, in CRC [65]. Hypoxia-inducible factor (Hif-1 $\alpha$ ) expression is regulated by MAPK, PI3k/Akt/mTOR, and epigenetic changes, and overexpression leads to tumor formation and neovascularization [66]. Vascular disrupting agents disrupt the endothelium of the tumor's vasculature. These new drugs are not associated with any biological markers at the present time.

\section{Adenocarcinoma of the Stomach}

Advanced gastric cancer is an incurable disease and the second leading cause of cancer mortality in the world. Many chemotherapeutic drugs have single-agent activity in advanced gastric cancer with response rates ranging from 10 to $30 \%$. Although combination chemotherapy has been shown to be more effective than single agents, response rates extend between 30 and $50 \%$ and progression-free survival with the best combinations ranges between 3 and 7 months with an overall survival between 8 and 11 months. New therapies are urgently needed. As is the case with many cancers, the most important prognostic factor for gastric carcinoma is tumor stage, evaluated by the pathologist, which is the depth of invasion of the gastric wall, the involvement of lymph nodes, and the 

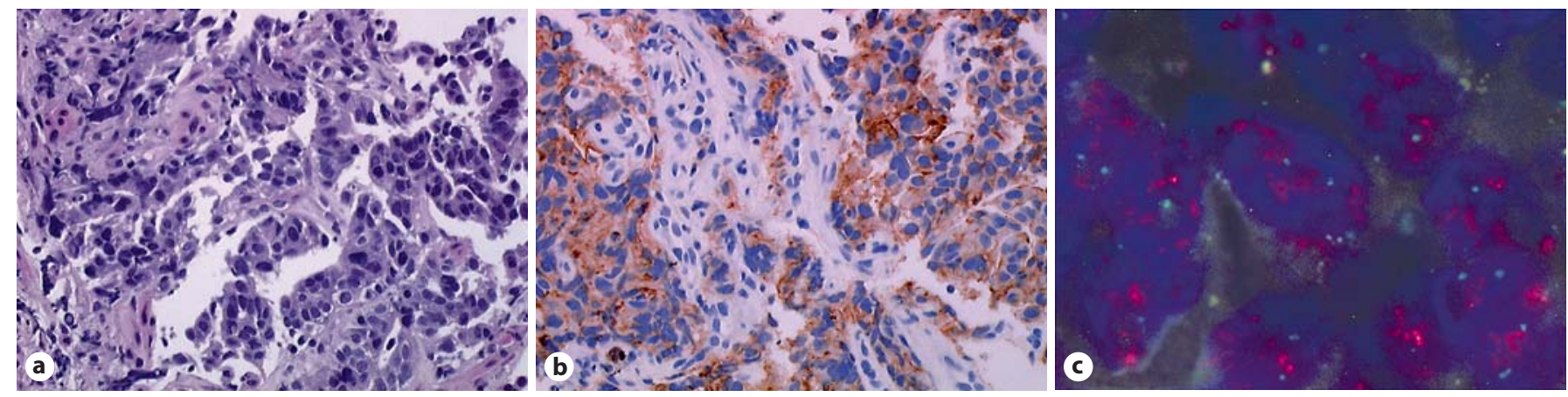

Fig. 6. HER2neu study in adenocarcinoma of the stomach. a H\&E section. Moderately differentiated adenocarcinoma with invasive distorted glands. b Her2neu overexpression on IHC (score 3+). c Her2 amplification on double-probe fluorescence in situ hybridization with multiple red spots.

presence of distant metastases. Other potential biomarkers could actually be evidenced to identify a biologic subset of this disease by morphological methods.

\section{HER 2}

HER 2 overexpression has been reported in $6-35 \%$ of gastric and gastroesophageal cancers (fig. 6). HER2 expression is higher in patients with intestinal cancer as compared to patients with diffuse types of cancers, as well in cancers of the gastroesophageal junction as compared to distal gastric cancers. The HER2 receptor contains an intracellular tyrosine kinase domain and binds to extracellular ligands [67]. Activation of HER2 induces a cascade of downstream signals through different pathways such as MAPK and PI3-kinase/Akt/mTOR, resulting in cellular proliferation, differentiation, survival, motility, adhesion, and repair [68]. In carcinoma, HER2 acts as an oncogene mainly because of high-level amplification of the gene inducing protein overexpression in the cellular membrane and the subsequent acquisition of advantageous properties for a malignant cell. In gastric carcinoma, HER2 overexpression has been correlated with poor outcomes and more aggressive disease [69]. Trastuzumab, a MoAb against HER2, has induced survival benefits when administered with chemotherapy in patients with HER2-positive (IHC/FISH) early and metastatic breast cancer. Patients with HER2-positive (IHC/ FISH) gastroesophageal and gastric adenocarcinomas (locally advanced, recurrent, or metastatic) show improvement with anti-HER 2 therapy associated with classical chemotherapy (5-fluorouracil or capecitabine and cisplatin) in the first-line setting (ToGA trial) (fig. 6). In accordance with the study by Hofmann et al. [70], the existing scoring systems for determining HER2 positivity in breast cancer samples cannot be applied and a specific score [71] has to be used to determine HER2 positivity in gastric cancer; they recommend using both IHC and FISH testing in clinical trials of trastuzumab treatment. Trastuzumab is a new, effective, and well-tolerated treatment for HER2-positive gastrointestinal cancers [72].

\section{MET}

Oncogenic mutations of MET have been found in gastric carcinoma [73, 74]. c-Met is a membrane-spanning tyrosine kinase receptor involved in several biological activities including motility, proliferation, survival, invasion, and morphogenesis $[75,76]$. HGF is the only known ligand for c-MET. Upon HGF binding, c-MET autophosphorylates and recruits several downstream effectors. cMET receptor expression is regulated by the MET protooncogene, and oncogenic mutations have been found in gastric carcinoma [77]. Several HGF/c-MET inhibitors, either MoAbs (ALG-102, OA-5D5) or small molecules (ARQ-197, XL-880), are under evaluation.

\section{Hepatocellular Carcinoma of the Liver}

Hepatocellular carcinoma (HCC) is a complex and heterogeneous highly chemoresistant tumor with several genetic alterations. Its incidence ranges from $<10$ cases per 100,000 persons a year in Northern America and Western Europe to $50-150$ cases per 100,000 persons in other parts of the world [78].

There is evidence of aberrant activation of several signaling cascades such as EGFR, Ras/extracellular signalregulated kinase, the phosphoinositol 3-kinase/mTOR, HGF/mesenchymal-epithelial transition factor, Wnt, 
Fig. 7. KIT and PDGFRA structure and exon mutations with their frequencies in GISTs.

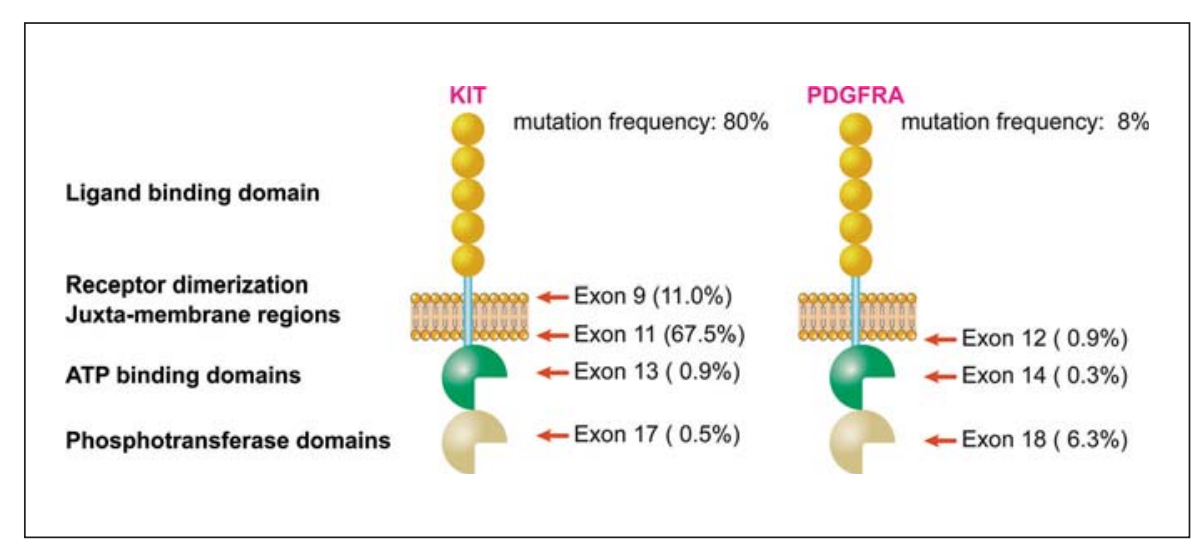

Hedgehog, and apoptotic signaling [79]. Of major interest are the growth factors and their receptors as well as their signaling pathways. It was discovered in 2007 that a multikinase inhibitor (sorafenib) showed for the first time a significant increase in overall survival in patients with advanced HCC [80]. This novel bi-aryl urea sorafenib $\left(\right.$ Nexavar $\left.^{\circledR}\right)$, an orally available multikinase inhibitor, targets kinases of wild-type B-Raf, mutant V559EB-Raf, and C-Raf, thereby blocking tumor growth. In addition, sorafenib inhibits the tyrosine kinase receptors involved in angiogenesis, including human VEGFR-2, VEGFR-3, and PDGF- $\beta R$. Molecular classification of HCC [81] based on genome investigations is able to identify subclasses according to drug sensitivity that will lead to more personalized medicine [82]. However, there is still no biomarker predicting sorafenib response in HCC.

\section{Adenocarcinoma of the Pancreas}

Pancreatic cancer is the fourth leading cause of cancer death in the United States. Gemcitabine-based therapy is an acceptable standard for unresectable locally advanced/ metastatic pancreatic cancer, but the average median survival is only 6 months. Activating RAS mutations have been found in more than $90 \%$ of pancreatic cancer cases [83].

The combination of gemcitabine and erlotinib, a smallmolecule tyrosine kinase inhibitor of the human EGFR, was recently approved by the US/European authorities for the first-line treatment of advanced pancreatic cancer. In a phase III trial, this combination demonstrated a significant improvement in overall survival compared with gemcitabine monotherapy [84]. In the future, treatment of pancreatic cancer may be influenced by the potential of certain biomarkers to predict better responses to molecular targeted therapies, allowing the individualization of patient therapy $[85,86]$.

\section{Gastrointestinal Stromal Tumors}

Gastrointestinal stromal tumors (GISTs) account for $80 \%$ of gastrointestinal mesenchymal tumors. They are rare as they constitute less than $3 \%$ of all gastrointestinal malignancies. [87-89]. On presentation, $41-47 \%$ of malignant GISTs are metastatic. Previously, these tumors were classified as gastrointestinal leiomyosarcomas, leiomyoblastomas, or schwannomas on the basis of histological findings such as spindle cells or epithelioid cells, characterized by nuclear palisading or prominent perinuclear vacuolization. GISTs apparently originate in the muscularis propria of the intestinal wall. In 1998, Hirota et al. [90] revolutionized this field, discovering that GISTs express the KIT protein, a membrane receptor with an intracellular tyrosine kinase component (antibody c-Kit or CD117), providing pathologists with an IHC diagnostic test. Independent of the location, most GISTs express the CD34 antigen (70-80\%) and the CD117 antigen (7294\%) (fig. 7). The CD34 protein is a hematopoietic progenitor cell antigen that is expressed in a variety of mesenchymal tumors. A new IHC marker, i.e. DOG1, which is a chloride channel protein, is highly specific for GISTs; however, it is exceptionally positive in other mesenchymal tumors like leiomyomas or synovial sarcomas. Negativity for both DOG1 and KIT has been observed in 2.6\% of GISTs of the gastrointestinal tract [91]. Interstitial cells of Cajal are gastrointestinal pacemaker cells that regulate intestinal motility and peristalsis. A relationship between GISTs and Cajal cells has been proposed because they 

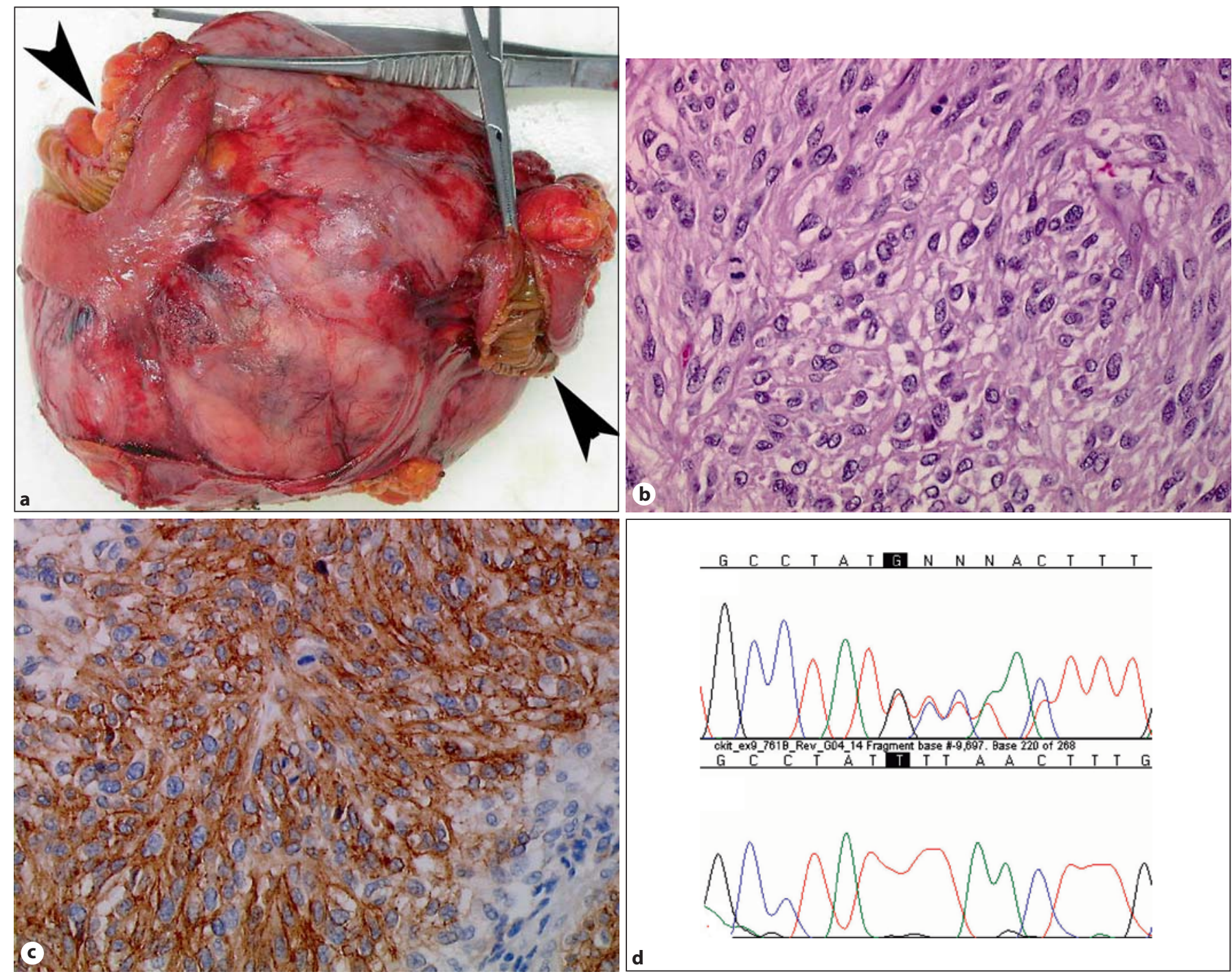

Fig. 8. An example of GIST with KIT mutation. a Macroscopy. Bulky tumor of the small bowel (black arrows) b H\&E section. Cellular proliferation with an epithelioid pattern. c Strong expression of KIT protein on IHC. d KIT exon 9 mutation evidenced by sequencing.

share the same expression of both CD34 and CD117 and of DOG1. Whether GISTs are Cajal cell tumors or whether they share a common progenitor cell is unknown. Patients with germline KIT or PDGFRA mutations resulting in KIT juxta-membrane aberrations have shown generalized Cajal cell hyperplasia and progression to discrete GISTs $[92,93]$.

About $10-30 \%$ of GISTs display malignant behavior. A GIST cannot be conclusively diagnosed as benign because even small, histologically benign-appearing tumors may later demonstrate clinically aggressive behavior. Factors that correlate with an improved prognosis in- clude gastric location, a diameter of less than $2 \mathrm{~cm}$, a low mitotic index, and an absence of tumor spillage with complete gross resection (fig. 7). In addition, Hirota et al. [89] discovered that in $80-86 \%$ of GISTs the KIT protein was mutated so that it provided an inappropriately high level of growth stimulation to the tumor cells due to a ligand-independent constitutive activation of the KIT receptor [94]. This finding raised the possibility that drug treatments that could inhibit KIT enzyme activity could be an effective treatment for GISTs. Imatinib mesylate is a selective inhibitor of the tyrosine kinase ABL, Abl-related gene product (ARG), KIT, CSF-1R, and platelet 
growth factor receptors alpha and beta. Imatinib is a competitive antagonist of the adenosine triphosphate binding site; by blocking the transfer of phosphate groups from ATP to tyrosine kinase residues, it causes interruption to the downstream signaling process that leads to cell proliferation, including MAP kinase and Akt (fig. 8) [95].

On the basis that imatinib developed as a tyrosine kinase receptor inhibitor [96], with a strong antiproliferative effect in vitro, a first patient was successfully treated with imatinib [97]. At the present time, two different kinase inhibitors (imitanib and sunitinib) are used for the treatment of GIST, and several other inhibitors are being tested for the treatment of imitanib- and/or sunitinibresistant tumors. In 2003, a subset of GISTs was discovered showing mutations in an other kinase receptor gene called PDGFRA 2 [98-100]. This gene encodes the platelet-derived growth factor receptor (alpha receptors) tyrosine kinase protein (fig. 8). Although surgery is the only curative treatment for GISTs, these tumors are remarkably sensitive to the KIT and PDGFRA kinase inhibitors imatinib $\left(\right.$ Gleevec ${ }^{\circledR}$ ) and sunitinib (Sutent ${ }^{\circledR}$ ) which have now been approved as standard treatment for patients with inoperable GISTs. They are recommended in the first-line treatment of unresectable or metastatic GISTs and recurrent disease. However, the clinical response to imatinib depends on the exonic location of KIT mutations in the GIST [101, 102]. KIT oncogenic mutations in exon 11, which are found in $75 \%$ of GISTs, abrogate the juxta-membrane-region autoinhibition of the KIT kinase. All of these juxta-membrane mutants are highly sensitive to imatinib and patients with such mutations have more than $80 \%$ clinical responses to imatinib [103]. The usual recommended starting dose is $400 \mathrm{mg}$ a day for tumors with KIT exon 11 mutations [101-104]. Patients that exhibit a mutation in the extracellular domain (exon 9; $13 \%$ of GISTs) need a double dose of imatinib. They gain a survival-free disease benefit with $800 \mathrm{mg} /$ day [99]. Rare tumors have mutations in the kinase 1 domain (exon 13 ; $1 \%$ ) or activation loop (exon $17 ;<1 \%$ ). Of the $20-25 \%$ of GISTs that have no KIT mutations, $8 \%$ have mutations in the platelet-derived growth factor receptor. Most mutations occur in the second kinase domain (exon 18; 85\%), and almost two thirds of these consist of a single point mutation D842V [100]. GISTs (10-20\%) exhibit primary resistance to imatinib $[105,106]$. However, clinical resistance to imatinib and sunitinib, not always due to therapeutic inobservance, was described in numerous patients and was in fact transitory when treatment was carried on. This resistance is supposed to result from secondary mutations in the KIT and/or PDGFRA kinase domain. Salvage therapies could include KIT transcriptional repression with flavopiridol and inhibition of the KIT oncoprotein chaperone HSP90+ [107].

Preoperative imatinib can decrease tumor volume and can be associated with complete surgical resection in locally advanced primary GISTs. Early surgical resection should be considered for imatinib-responsive recurrent or metastatic GISTs since complete resection is rarely achieved once tumor progression occurs $[104,108]$.

In conclusion, the more we understand the different pathways involved in gastrointestinal cancers and their relationships, the more we will find accurate targeted therapies. Target identification and validation place the pathologist in a central role in helping to answer the questions of how meaningful and realistic the possibilities are of tailoring cancer drugs with clinical relevance, accuracy, and sensitivity and of molecular pertinent classification of the tumors. Pathology is changing, providing and integrating increasingly novel diagnostic and prognostic information that allows more personalized drug prescription.

\section{Acknowledgment}

We thank Yves Chrétien (INSERM UMR-S 938) for the drawings.

\section{References}

1 Dy GK, Adjei AA: Systemic cancer therapy: evolution over the last 60 years. Cancer 2008; 113(suppl 7):1857-1887.

-2 Jemal A, Siegel R, Ward E, Hao Y, Xu J, Murray T, Thun MJ: Cancer statistics, 2008. CA Cancer J Clin 2008;58:71-96.

3 Hanahan D, Weinberg RA: The hallmarks of cancer. Cell 2000;100:57-70.

\footnotetext{
4 Adjei AA, Hidalgo M: Treating cancer by blocking cell signals. J Clin Oncol 2005;10; 23:5279-5280.

5 Iannello A, Ahmad A: Role of antibody-dependent cell-mediated cytotoxicity in the efficacy of therapeutic anti-cancer monoclonal antibodies. Cancer Metastasis Rev 2005; 24:487-499.
}

\footnotetext{
6 Cunningham D, Humblet Y, Siena S, Khayat D, Bleiberg H, Santoro A, Bets D, Mueser M, Harstrick A, Verslype C, Chau I, Van Cutsem E: Cetuximab monotherapy and cetuximab plus irinotecan in irinotecan-refractory metastatic colorectal cancer. N Engl J Med 2004;22;351:337-345.
} 
7 Moore MJ, Goldstein D, Hamm J, Figer A, Hecht JR, Gallinger S, Au HJ, Murawa P, Walde D, Wolff RA, Campos D, Lim R, Ding K, Clark G, Voskoglou-Nomikos T, Ptasynski M, Parulekar W, National Cancer Institute of Canada Clinical Trials Group: Erlotinib plus gemcitabine compared with gemcitabine alone in patients with advanced pancreatic cancer: a phase III trial of the $\mathrm{Na}$ tional Cancer Institute of Canada Clinical Trials Group. J Clin Oncol 2007;25:19601966.

8 Shepherd FA: A targeted approach to reducing lung cancer mortality. J Clin Oncol 2005; 23:3173-3174.

\$9 Hurwitz H: Integrating the anti-VEGF-A humanized monoclonal antibody bevacizumab with chemotherapy in advanced colorectal cancer. Clin Colorectal Cancer 2004;4(suppl 2):S62-S68.

10 Hamilton SR: Targeted therapy of cancer: new roles for pathologists in colorectal cancer. Mod Pathol 2008;21(suppl 2):S23-S30.

- 11 Bralet MP, Paule B, Falissard B, Adam R, Guettier C: Immunohistochemical variability of epidermal growth factor receptor (EGFR) in liver metastases from colonic carcinomas. Histopathology 2007;50:210-216.

$\checkmark 12$ Messick CA, Sanchez J, Dejulius KL, Church JM, Kalady MF: Genetic and molecular diversity of colon cancer hepatic metastases Surgery 2009; 146:227-231.

-13 Van Krieken JHJM, Jung A, Kirchner T, Carneiro F, Seruca R, Bosman FT, Quirke P, Fléjou JF, Plato Hansen T, de Hertogh G, Jares $\mathrm{P}$, Langner C, Ligtenberg M, Tiniakos D, Tejpar S, Bevilacqua G, Ensari A: KRAS mutation testing for predicting response to antiEGFR therapy for colorectal carcinoma: proposal for an European quality assurance program. Virchows Arch 2008;453:417-431.

-14 Tibiletti PG: Interphase FISH as a new tool in tumor pathology. Cytogenet Genome Res 2007;118:229-236.

15 Ciardiello F, Tortora G: EGFR antagonists in cancer treatment. N Engl J Med 2008;358: 1160-1174.

$\checkmark 16$ You WK, McDonald DM: The hepatocyte growth factor/c-Met signalling pathway as a therapeutic target to inhibit angiogenesis. BMB Rep 2008;41:833-839.

17 Carpenter G, Cohen S: Epidermal growth factor. J Biol Chem 1990;265:7709-7712.

18 Harding J, Burtness B: Cetuximab: an epidermal growth factor receptor chemeric human-murine monoclonal antibody. Drugs Today (Barc) 2005;41:107-127.

$\checkmark 19$ Walter O, Prasad M, Lu S, Quinlan RM, Edmiston KL, Khan A: IMP3 is a novel biomarker for triple negative invasive mammary carcinoma associated with a more aggressive phenotype. Hum Pathol 2009;40: 1528-1533.

20 Yarden Y, Sliwkowski MX: Untangling the ErbB signalling network. Nat Rev Mol Cell Biol 2001;2:127-137.
1 Zhong L, Guo XN, Zhang XH, Sun QM, Tong LJ, Wu ZX, Luo XM, Jiang HL, Nan FJ, Zhang XW, Lin LP, Ding J: TKI-31 inhibits angiogenesis by combined suppression signalling pathway of VEGFR2 and PDGFRbeta. Cancer Biol Ther 2006;5:323-330.

22 Hurwitz H, Fehrenbacher L, Novotny W, Cartwright T, Hainsworth J, Heim W, Berlin J, Baron A, Griffing S, Holmgren E, Ferrara N, Fyfe G, Rogers B, Ross R, Kabbinavar F: Bevacizumab plus irinotecan, fluorouracil, and leucovorin for metastatic colorectal cancer. N Engl J Med 2004;350:2335-2342.

23 Maynard MA, Ohh M: The role of hypoxiainducible factors in cancer. Cell Mol Life Sci 2007;64:2170-2180.

24 Ching LM, Cao Z, Kieda C, Zwain S, Jameson $\mathrm{MB}$, Baguley $\mathrm{BC}$ : Induction of endothelial cell apoptosis by the antivascular agent 5,6-Dimethylxanthenone-4-acetic acid (DMXAA), a novel antivascular agent: phase I clinical and pharmacokinetic study. Br J Cancer 2003;88:1160-1167.

25 Ma WW, Adjei, AA: Novel agents on the horizon for cancer therapy. CA Cancer J Clin 2009;59:111-137.

-26 Kushner DM, Silverman RH: Antisense cancer therapy: the state of the science. Curr Oncol Rep 2000;2:23-30.

27 Rosenberg SA, Yang JC, Restifo NP: Cancer immunotherapy: moving beyond current vaccines. Nat Med 2004;10:909-915.

28 Sawyer TK: Novel oncogenic protein kinase inhibitors for cancer therapy. Curr Med Chem Anticancer Agents 2004;4:449-455.

29 Iannello A, Ahmad A: Role of antibody-dependent cell-mediated cytotoxicity in the efficacy of therapeutic anti-cancer monoclonal antibodies. Cancer Metastasis Rev 2005; 24:487-499.

30 Gewirtz AM: On future's doorstep: RNA interference and the pharmacopeia of tomorrow. J Clin Invest 2007;117:3612-3614.

-31 Weiner GJ: Monoclonal antibody mechanisms of action in cancer. Immunol Res 2007:39:271-278.

32 Kohler G, Milstein C: Continuous cultures of fused cells secreting antibody of predefined specificity. Nature 1975;256:495-497.

33 Caron C, Boyault C, Khochbin S: Regulatory cross-talk between lysine acetylation and ubiquitination: role in the control of protein stability. Bioessays 2005;27:408-415.

34 Fedier A, Dedes KJ, Imesch P, Von Bueren AO, Fink D: The histone deacetylase inhibitors suberoylanilide hydroxamic (Vorinostat) and valproic acid induce irreversible and MDR1-independent resistance in human colon cancer cells. Int J Oncol 2007;31: 633-641.
35 Kim MS, Louwagie J, Carvalho B, Terhaar Sive Droste JS, Park HL, Chae YK, Yamashita K, Liu J, Ostrow KL, Ling S, GuerreroPreston R, Demokan S, Yalniz Z, Dalay N, Meijer GA, Van Criekinge W, Sidransky D: Promoter DNA methylation of oncostatin $\mathrm{m}$ receptor-beta as a novel diagnostic and therapeutic marker in colon cancer. PLoS One 2009;4:e6555.

36 Haddad R, Ogilvie RT, Croitoru M, Muniz V, Gryfe R, Pollet A, Shanmugathasan P, Fitzgerald T, Law CH, Hanna SS, Jothy S, Redston M, Gallinger S, Smith AJ: Microsatellite instability as a prognostic factor in resected colorectal cancer liver metastases. Ann Surg Oncol 2004;11:977-982.

37 Kim GP, Colangelo LH, Wieand HS, Paik S, Kirsch IR, Wolmark N, Allegra CJ, National Cancer Institute: Prognostic and predictive roles of high-degree microsatellite instability in colon cancer: a National Cancer Institute-National Surgical Adjuvant Breast and Bowel Project Collaborative Study. J Clin Oncol 2007;25:767-772.

-38 Sinicrope FA, Sargent DJ: Clinical implications of microsatellite instability in sporadic colon cancers. Curr Opin Oncol 2009;21: 369-373.

-39 Des Guetz G, Uzzan B, Nicolas P, Schischmanoff O, Perret GY, Morere JF: Microsatellite instability does not predict the efficacy of chemotherapy in metastatic colorectal cancer: a systematic review and meta-analysis. Anticancer Res 2009;29:1615-1620.

40 Warusavitarne J, Schnitzler M: The role of chemotherapy in microsatellite unstable (MSI-H) colorectal cancer. Int J Colorectal Dis 2007;22:739-748.

-41 Grávalos C, García-Escobar I, García-Alfonso P, Cassinello J, Malón D, Carrato A: Adjuvant chemotherapy for stages II, III and IV of colon cancer. Clin Transl Oncol 2009;11: 526-533.

42 Zaanan A, Cuilliere-Dartigues P, Guilloux A, Parc Y, Louvet C, de Gramont A, Tiret E, Dumont S, Gayet B, Validire P, Fléjou JF, Duval A, Praz F: Impact of p53 expression and microsatellite instability on stage III colon cancer disease-free survival in patients treated by 5 -fluorouracil and leucovorin with or without oxaliplatin. Ann Oncol 2009;772780.

43 Mendelsohn J, Baselga J: Epidermal growth factor receptor targeting in cancer. Semin Oncol 2006;33:369-385.

44 Cartenì G, Fiorentino R, Vecchione L, Chiurazzi B, Battista C: Panitumumab a novel drug in cancer treatment. Ann Oncol 2007; 18(suppl 6):vi16-vi21.

45 Harari PM, Allen GW, Bonner JA: Biology of interactions: antiepidermal growth factor receptor agents. J Clin Oncol 2007;25:40574065. 
-46 Chung KY, Shia J, Kemeny NE, Shah M, Schwartz GK, Tse A, Hamilton A, Pan D, Schrag D, Schwartz L, Klimstra DS, Fridman D, Kelsen DP, Saltz LB: Cetuximab shows activity in colorectal cancer patients with tumors that do not express the epidermal growth factor receptor by immunohistochemistry. J Clin Oncol 2005;23:1803-1810.

-47 Lièvre A, Laurent-Puig P: Molecular biology in clinical cancer research: the example of digestive cancers (in French). Rev Epidemiol Sante Publique 2005;53:267-282.

-48 Moroni M, Veronese S, Benvenuti S, Marrapese G, Sartore-Bianchi A, Di Nicolantonio F, Gambacorta M, Siena S, Bardelli A: Gene copy number for epidermal growth factor receptor (EGFR) and clinical response to antiEGFR treatment in colorectal cancer: a cohort study. Lancet Oncol 2005;6:279-286.

-49 Sartore-Bianchi A, Moroni M, Veronese S, Carnaghi C, Bajetta E, Luppi G, Sobrero A, Barone C, Cascinu S, Colucci G, Cortesi E, Nichelatti M, Gambacorta M, Siena S: Epidermal growth factor receptor gene copy number and clinical outcome of metastatic colorectal cancer treated with panitumumab. J Clin Oncol 2007;25:3238-3245.

50 Lièvre A, Laurent-Puig P: Predictive factors of response to anti-EGFR treatments in colorectal cancer (in French). Bull Cancer 2008;95:133-140.

- 51 De Roock W, Piessevaux H, De Schutter J, Janssens M, De Hertogh G, Personeni N, Biesmans B, Van Laethem JL, Peeters M, Humblet Y, Van Cutsem E, Tejpar S: KRAS wild-type state predicts survival and is associated to early radiological response in metastatic colorectal cancer treated with cetuximab. Ann Oncol 2008;19:508-515.

\$52 Cappuzzo F, Finocchiaro G, Rossi E, Jänne PA, Carnaghi C, Calandri C, Bencardino K, Ligorio C, Ciardiello F, Pressiani T, Destro A, Roncalli M, Crino L, Franklin WA, Santoro A, Varella-Garcia M: EGFR FISH assay predicts for response to cetuximab in chemotherapy refractory colorectal cancer patients. Ann Oncol 2008;19:717-723.

53 Benvenuti S, Frattini M, Arena S, Zanon C, Cappelletti V, Coradini D, Daidone MG, Pilotti S, Pierotti MA, Bardelli A: PIK3CA cancer mutations display gender and tissue specificity patterns. Hum Mutat 2008;29:284288.

54 Hamada K, Monnai M, Kawai K, Nishime C, Kito C, Miyazaki N, Ohnishi Y, Nakamura M, Suemizu H: Liver metastasis models of colon cancer for evaluation of drug efficacy using NOD/Shi-scid IL2Rgammanull (NOG) mice. Int J Oncol 2008;32:153-159.

-55 Rajagopalan H, Bardelli A, Lengauer C, Kinzler KW, Vogelstein B, Velculescu VE: Tumorigenesis: RAF/RAS oncogenes and mismatch-repair status. Nature 2002;418: 934.
Frattini M, Saletti P, Romagnani E, Martin V, Molinari F, Ghisletta M, Camponovo A, Etienne LL, Cavalli F, Mazzucchelli L: PTEN loss of expression predicts cetuximab efficacy in metastatic colorectal cancer patients. Br J Cancer 2007;97:1139-1145.

57 Laurent-Puig P, Cayre A, Manceau G, Buc E, Bache J-B, Lecomte T, Rougier P, Lievre A, Landi B, Boige V, Ducreux M, Ychou M, Bibeau F, Bouché O, Reid J, Stone S, PenaultLlorca F: Analysis of PTEN, BRAF, and EGFR status in determining benefit from cetuximab therapy in wild-type KRAS metastatic colon cancer. J Clin Oncol 2009;27:5924-5930.

58 Velho S, Moutinho C, Cirnes L, Albuquerque C, Hamelin R, Schmitt F, Carneiro F, Oliveira C, Seruca R: BRAF, KRAS and PIK3CA mutations in colorectal serrated polyps and cancer: primary or secondary genetic events in colorectal carcinogenesis. BMC Cancer 2008;8:255.

59 Barault L, Charon-Barra C, Jooste V, de la Vega MF, Martin L, Roignot P, Rat P, Bouvier AM, Laurent-Puig P, Faivre J, Chapusot C, Piard F: Hypermethylator phenotype in sporadic colon cancer: study on a population-based series of 582 cases. Cancer Res 2008;68:8541-8546.

60 Kawaguchi M, Yanokura M, Banno K, Kobayashi Y, Kuwabara Y, Kobayashi M, Nomura H, Hirasawa A, Susumu N, Aoki D: Analysis of a correlation between the BRAF V600E mutation and abnormal DNA mismatch repair in patients with sporadic endometrial cancer. Int J Oncol 2009;34:1541-1547.

61 Li C, Iida M, Dunn EF, Ghia AJ, Wheeler DL: Nuclear EGFR contributes to acquired resistance to cetuximab. Oncogene 2009;28: 3801-3813.

62 Bibeau F, Lopez-Crapez E, Di Fiore F, Thezenas S, Ychou M, Blanchard F, Lamy A, Penault-Llorca F, Frebourg T, Michel P, Sabourin J-C, Boissiere-Michot F: Impact of Fc\{gamma\}RIIa-Fc\{gamma\}RIIIa polymorphisms and KRAS mutations on the clinical outcome of patients with metastatic colorectal cancer treated with Cetuximab plus Irinotecan. J Clin Oncol 2009;27:1122-1129.

63 Folkman J, Merler E, Abernathy C, Williams G: Isolation of a tumor factor responsible for angiogenesis. J Exp Med 1971;133:275-288.

-64 Takahashi Y, Kitadai Y, Bucana CD, Cleary KR, Ellis LM: Expression of vascular endothelial growth factor and its receptor, KDR, correlates with vascularity, metastasis, and proliferation of human colon cancer. Cancer Res 1995;55:3964-3968.

65 Giantonio BJ, Catalano PJ, Meropol NJ, O'Dwyer PJ, Mitchell EP, Alberts SR, Schwartz MA, Benson AB 3rd, Eastern Cooperative Oncology Group Study E3200: Bevacizumab in combination with oxaliplatin, fluorouracil, and leucovorin (FOLFOX4) for previously treated metastatic colorectal cancer: results from the Eastern Cooperative Oncology Group Study E3200. J Clin Oncol 2007;25:1539-1544.
66 Pugh CW, Ratcliffe PJ: Regulation of angiogenesis by hypoxia: role of the HIF system. Nat Med 2003:677-684.

67 Coussens L, Yang-Feng TL, Liao YC, Chen E, Gray A, McGrath J, Seeburg PH, Libermann TA, Schlessinger J, Francke U, Levinson A, Ullrich A: Tyrosine kinase receptor with extensive homology to EGF receptor shares chromosomal location with neu oncogene. Science 1985;230:1132-1139.

68 Red Brewer M, Choi SH, Alvarado D, Moravcevic K, Pozzi A, Lemmon MA, Carpenter G: The juxtamembrane region of the EGF receptor functions as an activation domain. Mol Cell 2009;34:641-651.

69 Gravalos C, Jimeno A: HER2 in gastric cancer: a new prognostic factor and a novel therapeutic target. Ann Oncol 2008;19:15231529.

70 Hofmann M, Stoss O, Shi D, Büttner R, van de Vijver M, Kim W, Ochiai A, Rüschoff J, Henkel T: Assessment of a HER2 scoring system for gastric cancer: results from a validation study. Histopathology 2008;52:797-805.

-71 Rüschoff J, Dietel M, Baretton G, Arbogast S, Walch A, Monges G, Chenard M-P, PenaultLlorca F, Nagelmeier I, Schlake W, Höfler H, Keipe HH: Her2 diagnostics in gastric cancer - guideline validation and development of standardized immunohistochemical testing. Virchows Arch 2010;457:299-307.

72 Van Cutsem E, Kang Y, Chung H, Shen L, Sawaki A, Lordick F, Hill J, Lehle M, Feyereislova A, Bang Y: Efficacy results from the ToGA trial: a phase III study of trastuzumab added to standard chemotherapy (CT) in first-line human epidermal growth factor receptor 2 (HER2)-positive advanced gastric cancer (GC). J Clin Oncol 2009:27:18s.

$\checkmark 73$ Lee JH, Han SU, Cho H, Jennings B, Gerrard B, Dean M, Schmidt L, Zbar B, Vande Woude GF: A novel germ line juxtamembrane Met mutation in human gastric cancer. Oncogene 2000;19:4947-4953.

74 Park WS, Oh RR, Kim YS, Park JY, Shin MS, Lee HK, Lee SH, Yoo NJ, Lee JY: Absence of mutations in the kinase domain of the Met gene and frequent expression of Met and HGF/SF protein in primary gastric carcinomas. APMIS 2000;108:195-200.

75 Birchmeier C, Birchmeier W, Gherardi E, Vande Woude GF: Met, metastasis, motility and more. Nat Rev Mol Cell Biol 2003;4:915925 .

76 Rosário M, Birchmeier W: How to make tubes: signalling by the Met receptor tyrosine kinase. Trends Cell Biol 2003;13:328335.

$77 \mathrm{Yu}$ J, Miehlke S, Ebert MP, Hoffmann J, Breidert M, Alpen B, Starzynska T, Stolte M, Malfertheiner P, Bayerdörffer E: Frequency of TPR-MET rearrangement in patients with gastric carcinoma and in first-degree relatives. Cancer 2000;88:1801-1806. 
78 Capocaccia R, Sant M, Berrino F, Simonetti A, Santi V, Trevisani F, EUROCARE Working Group: Hepatocellular carcinoma: trends of incidence and survival in Europe and the United States at the end of the 20th century. Am J Gastroenterol 2007;102:16611670 .

79 Llovet JM, Bruix J: Molecular targeted therapies in hepatocellular carcinoma. Hepatology 2008:48:1312-1327.

80 Llovet JM, Ricci S, Mazzaferro V, Hilgard P, Gane E, Blanc JF, de Oliveira AC, Santoro A, Raoul JL, Forner A, Schwartz M, Porta C, Zeuzem S, Bolondi L, Greten TF, Galle PR, Seitz JF, Borbath I, Häussinger D, Giannaris T, Shan M, Moscovici M, Voliotis D, Bruix J, SHARP Investigators Study Group: Sorafenib in advanced hepatocellular carcinoma. N Engl J Med 2008:359:378-390.

-81 Chiang DY, Villanueva A, Hoshida Y, Peix J, Newell P, Minguez B, LeBlanc AC, Donovan DJ, Thung SN, Solé M, Tovar V, Alsinet C, Ramos AH, Barretina J, Roayaie S, Schwartz M, Waxman S, Bruix J, Mazzaferro V, Ligon AH, Najfeld V, Friedman SL, Sellers WR, Meyerson M, Llovet JM: Focal gains of VEGFA and molecular classification of hepatocellular carcinoma. Cancer Res 2008;68: 6779-6788.

-82 Mínguez B, Tovar V, Chiang D, Villanueva A, Llovet JM: Pathogenesis of hepatocellular carcinoma and molecular therapies. Curr Opin Gastroenterol 2009:25:186-194.

-83 Schönleben F, Qiu W, Allendorf JD, Chabot JA, Remotti HE, Su GH: Molecular analysis of PIK3CA, BRAF, and RAS oncogenes in periampullary and ampullary adenomas and carcinomas. J Gastrointest Surg 2009;13: 1510-1516.

-84 Rocha-Lima CM: New directions in the management of advanced pancreatic cancer: a review. Anticancer Drugs 2008;19:435446 .

85 Benson AB, Moore M: Accomplishments in 2007 in the management of localized pancreatic cancer. Gastrointest Cancer Res 2008; 2(3 suppl):S32-S36.

86 Jimeno A, Chan A, Cusatis G, Zhang X, Wheelhouse J, Solomon A, Chan F, Zhao M, Cosenza SC, Ramana Reddy MV, Rudek MA, Kulesza P, Donehower RC, Reddy EP, Hidalgo M: Evaluation of the novel mitotic modulator ON 01910.Na in pancreatic cancer and preclinical development of an ex vivo predictive assay. Oncogene 2009;28:610 618.

87 Cichoz-Lach H, Kasztelan-Szczerbińska B, Słomka M: Gastrointestinal stromal tumors: epidemiology, clinical picture, diagnosis, prognosis and treatment. Pol Arch Med Wewn 2008;118:216-221.
88 DeMatteo RP, Lewis JJ, Leung D, Mudan SS, Woodruff JM, Brennan MF: Two hundred gastrointestinal stromal tumors: recurrence patterns and prognostic factors for survival. Ann Surg 2000;231:51-58.

89 Plaat BE, Hollema H, Molenaar WM, Torn Broers GH, Pijpe J, Mastik MF, Hoekstra HJ, van den Berg E, Scheper RJ, van der Graaf WT: Soft tissue leiomyosarcomas and malignant gastrointestinal stromal tumors: differences in clinical outcome and expression of multidrug resistance proteins. J Clin Oncol 2000; 18:3211-3220.

90 Hirota S, Isozaki K, Moriyama Y, Hashimoto K, Nishida T, Ishiguro S, Kawano K, Hanada M, Kurata A, Takeda M, Muhammad Tunio G, Matsuzawa Y, Kanakura Y, Shinomura Y, Kitamura Y: Gain-of-function mutations of c-kit in human gastrointestinal stromal tumors. Science 1998;279:577-580.

91 Miettinen M, Wang ZF, Lasota J: DOG1 antibody in the differential diagnosis of gastrointestinal stromal tumors: a study of 1,840 cases. Am J Surg Pathol 2009;33:1401-1408.

92 Lasota J, Jasinski M, Sarlomo-Rikala M, Miettinen M: Mutations in exon 11 of c-Kit occur preferentially in malignant versus benign gastrointestinal stromal tumors and do not occur in leiomyomas or leiomyosarcomas. Am J Pathol 1999;154:53-60.

93 Tazawa K, Tsukada K, Makuuchi H, Tsutsumi Y: An immunohistochemical and clinicopathological study of gastrointestinal stromal tumors. Pathol Int 1999;49:786-798.

94 Heinrich MC, Griffith DJ, Druker BJ, Wait CL, Ott KA, Zigler AJ: Inhibition of c-kit receptor tyrosine kinase activity by STI 571, a selective tyrosine kinase inhibitor. Blood 2000;96:925-932.

$>95$ Tuveson DA, Willis NA, Jacks T, Griffin JD, Singer S, Fletcher CD, Fletcher JA, Demetri GD: STI571 inactivation of the gastrointestinal stromal tumor c-KIT oncoprotein: biological and clinical implications. Oncogene 2001;20:5054-5058.

$\$ 96$ Joensuu H, Roberts PJ, Sarlomo-Rikala M, Andersson LC, Tervahartiala P, Tuveson D, Silberman S, Capdeville R, Dimitrijevic S, Druker B, Demetri GD: Effect of the tyrosine kinase inhibitor STI571 in a patient with a metastatic gastrointestinal stromal tumor. N Engl J Med 2001;344:1052-1056.

$\$ 97$ Hirota S, Ohashi A, Nishida T, Isozaki K, Kinoshita K, Shinomura Y, Kitamura Y: Gain-of-function mutations of platelet-derived growth factor receptor alpha gene in gastrointestinal stromal tumors. Gastroenterology 2003;125:660-667.

98 Heinrich MC, Corless CL, Duensing A, McGreevey L, Chen CJ, Joseph N, Singer S, Griffith DJ, Haley A, Town A, Demetri GD, Fletcher CD, Fletcher JA: PDGFRA activating mutations in gastrointestinal stromal tumors. Science 2003;299:708-710.
99 Corless CL, Schroeder A, Griffith D, Town A, McGreevey L, Harrell P, Shiraga S, Bainbridge T, Morich J, Heinrich MC: PDGFRA mutations in gastrointestinal stromal tumors: frequency, spectrum and in vitro sensitivity to imatinib. J Clin Oncol 2005;23: 5357-5364.

100 Rink L, Skorobogatko Y, Kossenkov AV, Belinsky MG, Pajak T, Heinrich MC, Blanke CD, von Mehren M, Ochs MF, Eisenberg B, Godwin AK: Gene expression signatures and response to imatinib mesylate in gastrointestinal stromal tumor. Mol Cancer Ther 2009;8:2172-2182.

101 Heinrich MC, Corless CL, Blanke CD, Demetri GD, Joensuu H, Roberts PJ, Eisenberg BL, von Mehren M, Fletcher CD, Sandau K, McDougall K, Ou WB, Chen CJ, Fletcher JA: Molecular correlates of imatinib resistance in gastrointestinal stromal tumors. J Clin Oncol 2006;24: 4764-4774.

102 Blay JY: Pharmacological management of gastrointestinal stromal tumours: an update on the role of sunitinib. Ann Oncol 2010;21:208-215.

103 Heinrich MC, Corless CL: Gastric GI stromal tumors (GISTs): the role of surgery in the era of targeted therapy. J Surg Oncol 2005;90:195-207.

104 Blay JY, Bonvalot S, Casali P, Choi H, Debiec-Richter M, Dei Tos AP, Emile JF, Gronchi A, Hogendoorn PC, Joensuu H, Le Cesne A, McClure J, Maurel J, Nupponen N, Ray-Coquard I, Reichardt P, Sciot R, Stroobants $S$, van Glabbeke M, van Oosterom A, Demetri GD, GIST consensus meeting panellists. Consensus meeting for the management of gastrointestinal stromal tumors: report of the GIST Consensus Conference of 20-21 March 2004, under the auspices of ESMO. Ann Oncol 2005;16:566-578.

105 Demetri GD, Heinrich MC, Fletcher JA, Fletcher CD, Van den Abbeele AD, Corless CL, Antonescu CR, George S, Morgan JA, Chen MH, Bello CL, Huang X, Cohen DP, Baum CM, Maki RG: Molecular target modulation, imaging, and clinical evaluation of gastrointestinal stromal tumor patients treated with sunitinib malate after imatinib failure. Clin Cancer Res 2009:15: 5902-5909.

106 Druker BJ: Overcoming resistance to imatinib by combining targeted agents. Mol Cancer Ther 2003;2:225-226.

107 Fletcher JA, Rubin BP: KIT mutations in GIST. Curr Opin Genet Dev 2007;17:3-7.

108 Bonvalot S, Eldweny H, Péchoux CL, Vanel D, Terrier P, Cavalcanti A, Robert C, Lassau $\mathrm{N}$, Cesne AL: Impact of surgery on advanced gastrointestinal stromal tumors (GIST) in the imatinib era. Ann Surg Oncol 2006;13:1596-1603. 